\title{
Türkiye’de retinal ven tıkanıklığı tanısında endikasyon dışı ilaç kullanımı
}

\section{Off-label drug use in diagnosis of retinal vein occlusion in Turkey}

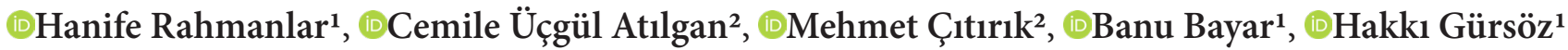 \\ ${ }^{1}$ Türkiye Tibbi İlaç ve Cihaz Kurumu Başkanlığı, Ankara, Türkiye \\ ${ }^{2}$ Ulucanlar Göz Eğitim ve Araştırma Hastanesi, Göz Kliniği, Ankara, Türkiye
}

Cite this article as / Bu makaleye atıf için: Rahmanlar H, Üçgül Atılgan C, Çıtırık M, Bayar B, Gürsöz H. Türkiye'de retinal ven tıkanıklı̆̆ı tanısında endikasyon dışı ilaç kullanımı. J Med Palliat Care 2021; 2(1): 15-20.

\section{ÖZ}

Amaç: Türkiye'de retinal ven tıkanıklığı (RVT) olan hastalarda endikasyon dışı ilaç kullanımı için yapılan başvuruların demografik özelliklerini değerlendirmek.

Gereç ve Yöntem: 1 Ocak ile 31 Aralık 2013 tarihleri arasında Türkiye İlaç ve Tıbbi Cihaz Kurumu Başkanlığına, Türkiye genelindeki hastanelerden RVT tanısı ile endikasyon dışı ilaç kullanımı (deksametazon implant, ranibizumab, bevasizumab, aflibersept) için yapılan başvurular geriye dönük olarak incelendi. Olguların dosyaları demografik veriler, önceki tedavi rejimleri, başvuru gerekçeleri, ilacın istenilen doz ve kullanımı açısından değerlendirildi.

Bulgular: Çalışmaya RVT tanısı ile endikasyon dışı ilaç kullanımı başvurusu kabul edilen 30 hasta dâhil edildi. Hastaların ortalama yaşı $64,43 \pm 9,48$ yıldı ve \%56,7'si erkek, \%43,3'ü kadındı. Bu başvuruların \%70’ini deksametazon implant, \%30’unu ise ranibizumab oluşturmaktaydı. Başvuruların bölgelere göre dağılımında ilk iki sırada, İç Anadolu (\%66,6) ve Ege (\%23,3) bölgesi yer almaktaydı. Başvuru yapan hastanelerin dağılımında ise $\% 80$ oranıyla devlet üniversitesi 1 . sırada, \%13,3 oranıyla eğitim ve araştırma hastanesi 2 . sırada, \%6,7 oranıyla ise vakıf üniversitesi 3. sırada bulunmaktaydı. Başvuru yapan hastaların 5’i (\%16,7) önceden aldığı tedavi rejimi olmayan naif hastalardan oluşmakta iken, 11'i $(\% 36,7)$ başvuru öncesinde ranibizumab tedavisi almaktaydı.

Sonuç: Ciddi görme kaybına neden olabilen RVT tedavisinde Türkiye’de endikasyon dışı ilaç kullanımı başvuru bilgilerinin değerlendirilmesi, literatüre katkısının yanı sıra, tedavi seçeneklerimizi belirleme açısından yol gösterici olacaktır.

Anahtar Kelimeler: Endikasyon dışı ilaç, intravitreal tedavi, retinal ven tıkanıklığı

\begin{abstract}
Purpose: To evaluate the demographic characteristics of patients who use off-label drugs for retinal vein occlusion (RVO) in Turkey.

Material and Method: The applications for off-label drug use in patients with RVO (dexamethasone implant, ranibizumab, bevacizumab, aflibercept) from hospitals in Turkey to the Turkish Medicines and Medical Devices Agency from January to December 2013 were examined retrospectively. The files of the cases were evaluated in terms of demographic data, previous treatment regimens, reasons for application, dosage and usage of the drug.

Results: This study was enrolled 30 patients who were admitted for off-label drug use for retinal vein occlusion. The mean age of all patients was $64.43 \pm 9.48$ years and $56.7 \%$ of patients were male, $43.3 \%$ were female. Of these applications, $70 \%$ was dexamethasone implant, $30 \%$ was ranibizumab. The first two places in the distribution of the applications were Central Anatolia (66.6\%), Ege (23.3\%). In the distribution of the referring hospitals, the state universities were seen first rank with a rate of $80 \%$, the education and research hospitals were second rank with a ratio of $13.3 \%$ and the foundation universities were third rank with a rate of $6.7 \%$ of patients, five (16.7\%) were naïve patients with no previous treatment regimen and eleven patients (36.7\%) were previously treated with ranibizumab.

Conclusion: The evaluation of off-label drug use in the treatment of retinal vein occlusion will guide us in determining the treatment options in such a challenging treatment process in Turkey as well as its contribution to the literature.
\end{abstract}

Keywords: Intravitreal treatment, off-label drug, retinal vein occlusion 


\section{GíRiş}

Endikasyon terimi "ilacın kullanım alanı, etkili olduğu durum" olarak tanımlanmakta iken, "endikasyon dișı kullanım (off-label)" ise ruhsatlandırılmış bir ilacın ruhsatında belirtilen kullanım alanlarıve şartları dıșındaki koşullarda kullanılması olarak tanımlanmaktadır $(1,2)$. Ülkemizde ilacın ruhsatlandırma aşaması zorlu bir süreç olduğu için ilaç firmaları, ilacın etkili olduğu tüm durumlardan ziyade en önemli ve faydalı gördükleri kullanım alanlarına yönelik başvuruda bulunmayı tercih ederler. Ancak pratikte, ilacın ruhsat başvurunun kapsamı dışında etkili olduğu hastalıklarda kullanımı oldukça yaygindır (3).

Etkinliği randomize kontrollü çalışmalarda kanıtlanmasına rağmen yeni endikasyonların ilacın ruhsat kapsamına dâhil edilme sürecinin uzaması veya dahil edilmemesi hekimleri endikasyon dişı ilaç kullanımına yönlendirmektedir. Ayrıca o hastalığa yönelik alternatif tedavilerin maliyetinin çok oluşu, bu tedavilere erişimin zor olması ve alternatif tedavilerle benzer etkinlikleri göstermesi gibi sebepler de endikasyon dışı ilaç kullanımını birçok alanda olduğu gibi oftalmoloji pratiğinde de yaygın hale getirmiştir.

Retinal ven tıkanıklığı (RVT), diyabetik retinopatiden sonra retinanın ikinci sıklıkla görülen damarsal hastalığıdır (4). RVT, tıkanıklığın yerine göre santral retinal ven tıkanıklığı (SRVT) ya da retinal ven dal tıkanıklığı (RVDT) olmak üzere 2'ye ayrılır (5). RVT'deki görme kaybının en sık nedeni maküler ödemdir. Patogenezde vasküler endotelyal büyüme faktörleri (VEBF), interlökin (IL)-1alfa, IL-6, IL-8, monosit kemoatraktan protein-1, tümör nekrozis faktör alfa (TNF-alfa) gibi anjiyojenik ve inflamatuar sitokinler önemli rol oynamaktadır $(6,7)$. RVT ve buna bağlı görme keskinliğinin azalması nadiren geri dönüşümlü olmakla birlikte, tedavisiz kalan maküla ödemlerinde kalıcı görme kaybı gelişmektedir. RVT’ye bağlı görme kaybının tedavisinde VEBF inhibitörleri ve deksametazon implantı da içeren intravitreal steroid uygulanması önemli tedavi seçenekleri arasındadır (8).

Ranibizumab (Lucentis; Genentech, Inc., South San Francisco, CA), VEBF antikorunun antijen bağlayan parçasından (Fab) oluşur ve VEBF-A'nın biyolojik olarak aktif tüm izoformlarını bloke eder. RVT’ye bağlı makülar ödemdeki etkinliği birçok çalıșmada kanıtlanmıștır (911).

Bevacizumab (Avastin; Genentech, South San Francisco, CA, USA), VEBF'in tüm alt tiplerine bağlanarak yeni damar oluşumunu engelleyen bir insan antikordur. Sadece kolon kanserinin sistemik kullanımı (12) için ruhsatlı bir ilaç olmasına rağmen, pratikte birçok retinal vasküler patolojiye ikincil maküla ödemi ve yeni damar oluşumunda off-label olarak tüm dünyada olduğu gibi Türkiye’de de sıkça kullanılmaktadır. RVT’ye bağlı maküla ödemi ve iskemiye ikincil yeni damar oluşumlarının tedavisinde de kullanımı yaygındır $(13,14)$.

Aflibercept (Eylea; Regeneron, Tarrytown, NY, ABD ve Bayer, Leverkusen, Almanya), VEBF’in hücre dişı kısımlarına benzeyen bir füzyon proteinidir. VEGFA’nın tüm izoformlarına ek olarak VEBF-B ve plasental büyüme faktörünü de inhibe ederek etkili olmaktadır.

Yavaş salınımlı deksametazon implant (Ozürdex, Allergan Inc, Irvine CA) ise güçlü bir kortikosteroiddir.

$\mathrm{Bu}$ çalışmada Türkiye İlaç ve Tibbi Cihaz Kurumu Başkanlığına RVT'ye ikincil makula ödemi tedavisi için endikasyon dışı ilaç kullanımı başvurusu yapılan olguların demografik özelliklerinin incelenmesi amaçlanmıştır.

\section{GEREÇ VE YÖNTEM}

Bu klinik araştırmada 1 Ocak ile 31 Aralık 2013 tarihleri arasında Türkiye İlaç ve Tibbi Cihaz Kurumu Başkanlığı'na, Türkiye genelindeki hastanelerden RVT'ye bağlı endikasyon dışı ilaç kullanımı (deksametazon implant, ranibizumab, bevacizumab, aflibercept) için yapılan başvurular geriye dönük olarakincelendi. Çalışma için Türkiye İlaç ve Tibbi Cihaz Kurumu Başkanlığı’ndan yazılı izin alındıktan sonra Ankara Dışkapı Eğitim ve Araştırma Hastanesỉnden etik kurul izni alındı (Etik kurul karar numarası:49/12 tarih: 16.04.2018). Çalışma sürecinde Helsinki deklarasyonunda kabul edilen prensiplere bağlı kalındı.

Hastaların dosyaları demografik veriler, başvuru anında her ikigöziçin, en iyi düzeltilmiş görme keskinliği (Snellen eşeli ile), göz içi basınçları, biyomikroskopik ve dilate fundus muayene bulguları açısından değerlendirildi. Ayrıca tüm olguların önceki tedavi rejimleri, başvuru gerekçeleri, başvuru bölgesi, başvuru hastanesi, başvuru sonuçları kayıt altına alındı.

Veriler Statistical Package for the Social Sciences sürüm 17.0 (SPSS Inc., Chicago, IL, ABD) yazılımı kullanılarak analiz edildi. Çalışma verileri değerlendirilirken tanımlayıcı istatistiksel metotların (frekans, yüzde, ortalama, standart sapma) yanı sıra normal dağılımın incelenmesi için Kolmogorov-Smirnov dağılım testi kullanıldı.

\section{BULGULAR}

Çalışmamızda RVT tanısı ile endikasyon dışı ilaç kullanımı başvurusu yapan 30 hastanın dosyası geriye yönelik incelendi. Hastaların \%56,7'si erkek, \%43,3’ü kadındı. Tüm hastaların ortalama yaşı $64,43 \pm 9,48(48-85)$

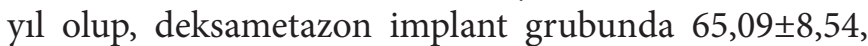


ranibizumab grubunda $62,88 \pm 11,82$ yıldı. Demografik veriler Tablo 1'de gösterilmektedir. 30 hastanın 18'i (\%60) RVDT tanısı ile, 12'si (\%40) ise SRVT tanısı ile başvuru yapmıştı (Tablo 1). Başvuruların \%70’ini oluşturan deksametazon implant 1. sirayı alırken bunu, \%30 oranıla ranibizumab takip etmekteydi. Bevacizumab ve aflibercept için ise o döneme ait endikasyon dışı ilaç kullanımı başvurusu yoktu (Grafik 1).

\begin{tabular}{|c|c|c|}
\hline Değişkenler & $\begin{array}{c}\text { Deksametazon } \\
\text { Implant } \\
\text { Ort } \pm \text { SS } \\
\mathbf{n}=21\end{array}$ & $\begin{array}{c}\text { Ranibizumab } \\
\text { Ort } \pm S S \\
n=9\end{array}$ \\
\hline $\begin{array}{l}\text { Yaş (yıl) } \\
\text { (aralık) }\end{array}$ & $\begin{array}{c}65,09 \pm 8,54 \\
(52-85)\end{array}$ & $\begin{array}{c}62,88 \pm 11,82 \\
(48-76)\end{array}$ \\
\hline Cinsiyet (K/E) & $12 / 9$ & $1 / 8$ \\
\hline $\begin{array}{l}\text { EİDGK (Ondalık) } \\
\text { Sağ } \\
\text { Sol }\end{array}$ & $\begin{array}{l}0,2 \pm 1 \\
0,3 \pm 1\end{array}$ & $\begin{array}{c}0,1 \pm 1 \\
0,01 \pm 1\end{array}$ \\
\hline $\begin{array}{l}\text { Fakik/Katarakt/Psödofak } \\
\text { Sağ } \\
\text { Sol }\end{array}$ & $\begin{array}{l}17 / 4 / 0 \\
16 / 4 / 1\end{array}$ & $\begin{array}{l}8 / 1 / 0 \\
8 / 1 / 0\end{array}$ \\
\hline $\begin{array}{l}\text { Teşhis: } \\
\text { SRVT } \\
\text { RVDT }\end{array}$ & $\begin{array}{l}10(\% 46,79 \\
11(\% 52,4)\end{array}$ & $\begin{array}{l}2(\% 22,2) \\
7(\% 77,8)\end{array}$ \\
\hline $\begin{array}{l}\text { Taraf: } \\
\text { Sağ } \\
\text { Sol } \\
\text { Bilateral }\end{array}$ & $\begin{array}{l}12 \\
9 \\
0\end{array}$ & $\begin{array}{l}3 \\
5 \\
1\end{array}$ \\
\hline
\end{tabular}

K: Kadın; E: Erkek; EİDK: En iyi düzeltilmis görme keskinliği; SS: Standard sapma; n: Hasta sayısı, SRVT:Santral retinal ven tıkanıklığı; RVDT:Retinal ven dal tıkanıklığ

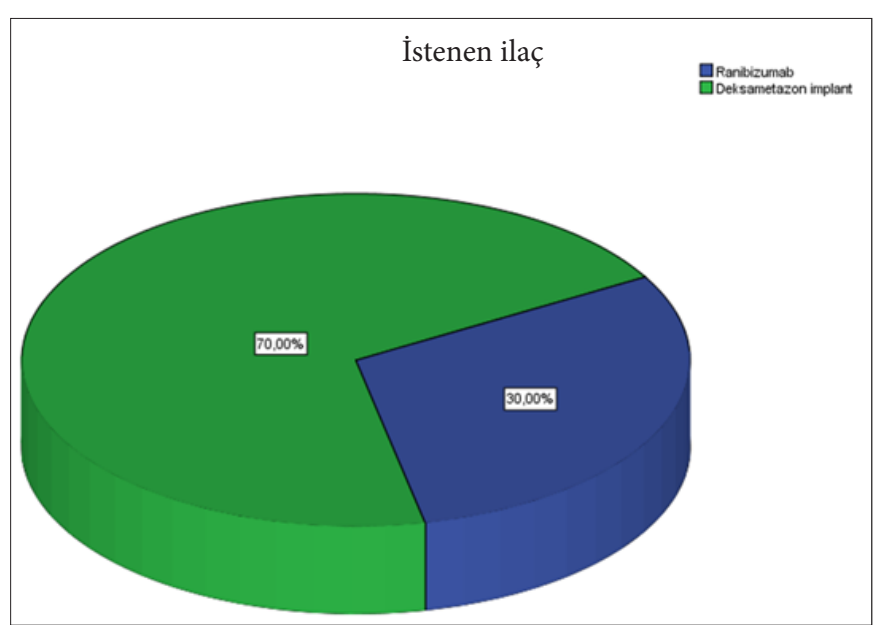

Grafik 1. Türkiye'de retinal ven tıkanıklığı hastalığında başvuru yapılan endikasyon dışı ilaçların dağılımı.

Başvuruların bölgelere göre dağılımında ilk iki sırayl, İç Anadolu $(\% 66,7)$ ve Ege $(\% 23,3)$ bölgeleri oluşturmaktaydı. Bunu, Karadeniz, Akdeniz ve Güneydoğu Anadolu bölgeleri aynı başvuru oranlarıyla izlerken (\%3,33, \%3,33, \%3,33 sırayla), Marmara ve Doğu Anadolu bölgelerinden o döneme ait başvuru kaydına rastlanmadi (Grafik 2).

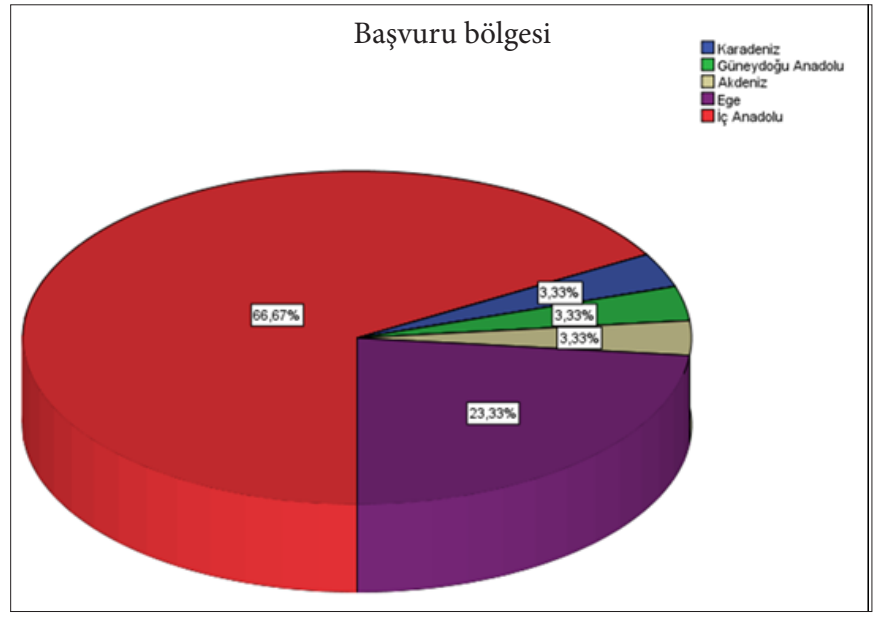

Grafik 2. Türkiye'de retinal ven tıkanıklığı tanısı için yapılan endikasyon dışı ilaç kullanımı başvurularının yedi bölgeye göre dağılım yüzdesi

Başvuru yapan hastaneler incelendiğinde ise $\% 80$ oranıyla devlet üniversitesi 1. sırada, $\% 16,3$ oranıly eğitim ve araştırma hastanesi ise 2. sırada, $\% 6,7$ oranıyla vakıf üniversitesi ise 3. sırada yer almaktaydı. Devlet hastanesi, özel hastane ya da dal hastanelerinden o döneme ait hiçbir başvuru yoktu (Grafik 3).

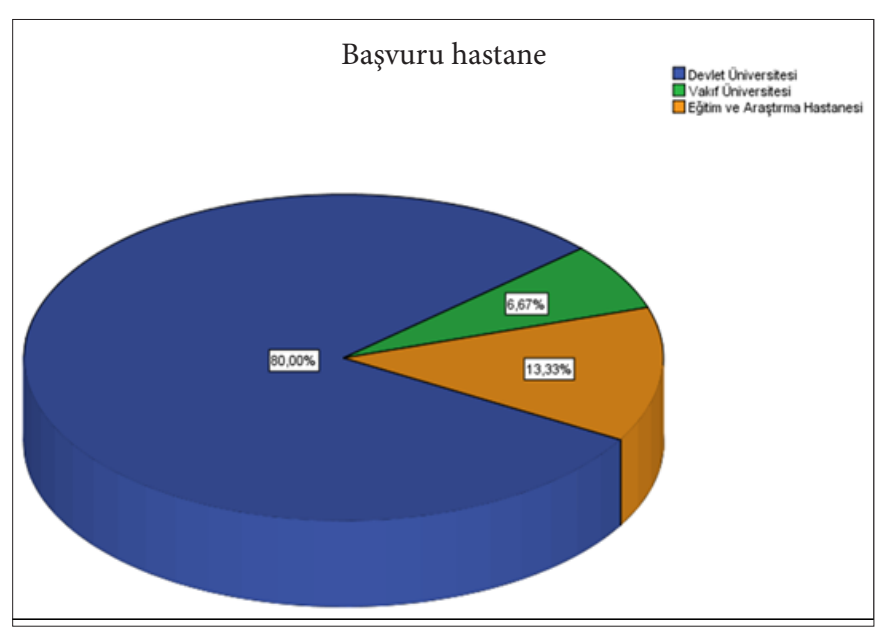

Grafik 3. Türkiye'de retinal ven tıkanıklığı hastalığında endikasyon dışı ilaç kullanımı başvurusu yapılan hastanelerin dağılımı

Hastaların önceki tedavi rejimleri Grafik 4'de görülmektedir. Buna göre deksametazon implant grubunda, ilk siralarda $\% 38,1$ (8 hasta) oraniyla sadece ranibizumab ve yine $\% 38,1$ ( 8 hasta) oraniyla deksametazon implant yer alırken, bunu \%14,3 (3 hasta) oraniyla ranibizumab ile birlikte intravitreal triamsinolon (IVTA) ve \%9,5 (2 hasta) oraniyla daha önce tedavi almamıs naif hastalar izlemekteydi. Ranibizumab grubunda ise \%44,4 oranlarıyla hiç tedavi almamıs naif hastalar ilk sırayı, \%33,3 oranıyla ranibizumab tedavisi almış hastalar ikinci sırayı, $\% 11,1$ oranlariyla bevacizumab, ranibizumab ile birlikte bevacizumab alan hastalar ise üçüncü sırayı oluşturmaktaydı. 


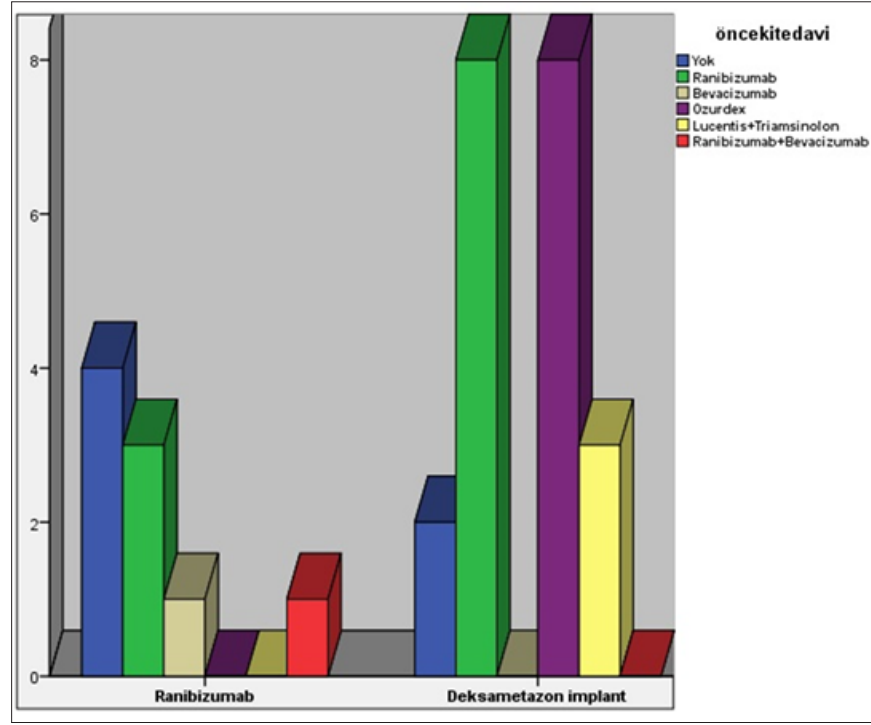

Grafik 4. Hastaların endikasyon dışı ilaç kullanım başvurusu yapmadan önceki tedavi rejimleri

Hastaların başvuru gerekçeleri Grafik 5'te gösterilmektedir. Buna göre deksametazon implant için $\% 85,7$ oranında üçüncü ve dördüncü doz deksametazon implant için başvuruda bulunma en önemli gerekçe olarak dikkati çekmektedir. Ranibizumab için ise \%100 oranıyla katarakt ve glokom riski nedeniyle başvuruda bulunma tek neden olarak belirtilmiştir.

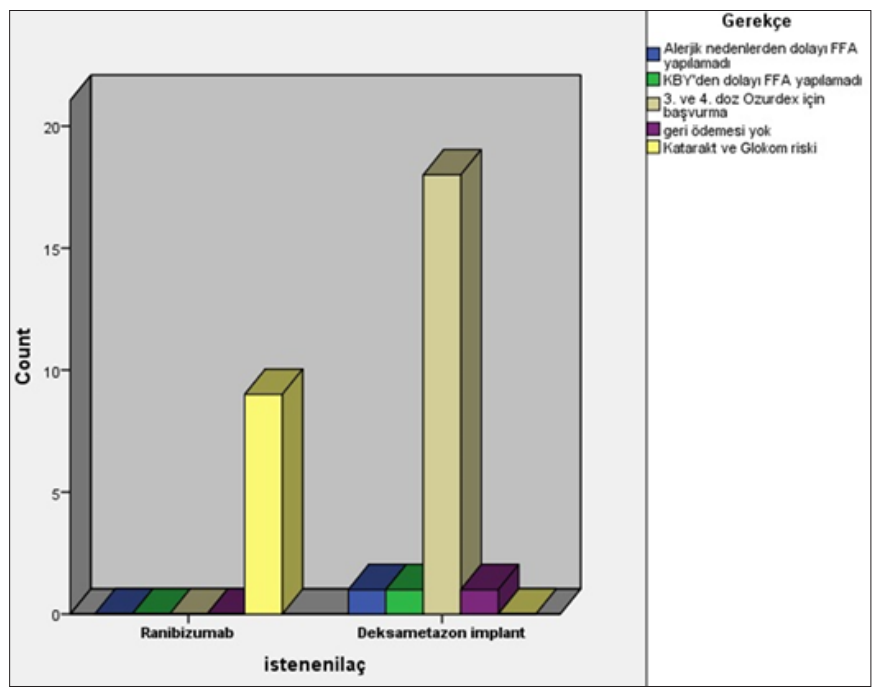

Grafik 4. Endikasyon dışı ilaç kullanımı başvuru gerekçeleri

\section{TARTIŞMA}

Her hangi bir hastalığın tedavisinde uygun olan, hekimin endikasyon dahilindeki ilaçlarla tedavi uygulamasıdır. Etkinliği birçok bilimsel araştırma ile kanıtlanmasına rağmen o hastalık için ruhsatlandırılamayan ilaçların kullanımı, dünyada ruhsatlandırılmış olsalar bile, endikasyon dışı kullanıma girmektedir. Ülkemizde onaylı endikasyon dahilindeki bir ilaçla tedavisi mümkün olan hastalıklar için endikasyon dışı ilaç kullanımının gerekçeleri arasında; hastaların sosyoekonomik durumu, alternatif tedavilerin maliyetli oluşu ve ilaçlar arasında benzer etkinlik görülmesi gibi sebepler ön plana çımaktadır. Bu amaçla hekimler ülkemizde İlaç ve Tibbi Cihaz Kurumuna (TİTCK) endikasyon dışı ilaç kullanımı için başvuru yapabilmektedirler. Başvuru formları TİTCK'deki bilimsel değerlendirme kurulu tarafından incelendikten sonra onaylanması halinde hasta, ilacını endikasyon dahilindeki ilaç gibi temin edebilmekte ve kullanabilmektedir.

Ancak oftalmoloji pratiğinde çok sık kullanılan bazı ilaçlar için bakanlık onayına gerek kalmadan direk kullanımı mümkündür. Bu amaçla Sağlık Bakanlığ TİTCK tarafından oluşturulan Ek-4 listesi mevcuttur. Sadece kolon kanseri için ruhsatlandırılmış olan bevacizumab 18.07.2014 tarihinden itibaren ülkemizde bakanlık onayına gerek kalmadan, proliferatif diyabetik retinopatide, diabetik makülerödemde, yaşa bağlı koroid neovaskülarizasyonu, RVT’ye bağlı maküler ödem gibi bazı hastalıklarda kullanılmaktadır. Bevacizumab'in benzer etkinliği gösteren başka onaylı VEBF inhibitörleri olmasına rağmen bu yaygın kullanımı, diğer VEBF inhibitörlerine nazaran daha ekonomik olması, endikasyon dişı ilaç kullanımı başvurusuna gerek kalmadan kullanılabilmesi ve kolay temin edilebilir oluşuyla açıklanabilir. Ayrıca Bevacizumab’ın bakanlık onayına gerek kalmadan kullanılması, bu konu ile ilgili gerçek kayıtların bilinememesine neden olmaktadır. Bizim çalışmamızda, 2013 yılında RVT tanısında bevacizumab kullanımı için hiç başvuru bulunmaması dikkat çekmektedir. Yukarıda bahsedilen nedenler göz önünde bulundurulduğunda bu konu ile ilgili gerçek verilerin çok daha fazla olduğunu düşünmekteyiz $(13,14)$.

Ülkemizde RVT tanısında ranibizumab etkin maddeli ilacin ruhsat onay tarihi 15.02.2011 iken geri ödeme onay tarihi 17.01.2013 tarihidir. Ayn tanıda aflibercept etkin maddeli ilacın ruhsat onay tarihi 19.09.2014 iken geri ödeme onay tarihi 27.02.2015 tarihidir. Yine aynı tanıda deksametazon implant etkin maddeli ilacin ruhsat onay tarihi 21.02.2012 iken geri ödeme onay tarihi 18.01.2013 tarihidir.

Retinal ven oklüzyonuna bağlı maküler ödemin patogenezinde, VEBFe bağlı kan-retina bariyerinin bozulmasıyla birlikte, inflamatuar stokinlerin damar geçirgenliğini arttırmasi; tedavisinde intravitreal steroidlerin kullanımını popüler hale getirmiştir. İlk olarak 2002 yllında intravitreal triamsinolon asetonidin (IVTA) santral RVT'de intravitreal olarak off-label kullanımı hem fonksiyonel hem de anatomik açıdan yüz güldürücü sonuçlar vermiştir. Daha sonraları 2012'de güçlü bir kortikosteroid olan yavaş salınımlı deksametazon implantın (Ozurdex, Allergan Inc, Irvine CA) üretilmesiyle ve RVT tedavisi için endikasyon dahiline girmesiyle IVTA’nın kullanımı azalmıştır. 
Ancak, hem IVTA hem de deksametazon implantın artmış göz içi basıncı ve erken katarakt oluşumu gibi önemli komplikasyonları vardır. Yapılan çalışmalarda IVTA uygulanan hastalarda deksametazon implant uygulanan hastalara kıyasla bu komplikasyonların daha sık görüldüğü ve daha zor kontrol altına alındığının bildirilmesiyle, benzer etkinliğe sahip endikasyon dahilinde bir ilaç varken, off-label bir ilacın tercih edilmesi yerine deksametazon implant daha ön plana çıkmıștır $(15,16)$. Ancak yine de IVTẢnın bakanlık onayına gerek kalmadan rahatça kullanılabilmesinden ötürü, bu alandaki gerçek kullanım oranını belirleyebilmek güçtür. Bu çalışmada 2013 yılında RVT'de deksametazon implant için başvuru oranı 21 hasta ile \%70'dir. Başvuru sayısının az olmasını ilacin 18.01.2013 tarihinde sosyal güvenlik kurumundan geri ödeme kapsamına girmesiyle ya da IVTA'nın bu amaçla halen bazı hekimler tarafından tercih edilebilmesiyle açıklayabiliriz. İntravitreal uygulanan deksametazon implantın ilk 2 ay hızlı salınım, sonraki 4 ay yavaş salınım göstererek 6 aya kadar etkisini sürdürebildiği belirtilmektedir $(16,17)$. Ancak yapılan çalışmalar ilk 4 ay sonrasında etkisinin azaldığı yönündedir ve 6 ayı beklemeden tekrarlayan enjeksiyonlara gerek duyulabilmektedir. Bir ilacın kullanım alanını ve kullanım şartlarını prospektüsündeki bilgiler belirlemektedir. Deksametazon implant için "1 yılda 2 kez kullanılabilir" ibaresinden dolayı 1 yıl içinde 3. doz deksametazon implantı temin edebilmek için endikasyon dişı kullanımı başvurusunda bulunmak gerekmektedir. Bu çalışmada da 2013 yılında RVT'de deksametazon implant için başvuru yapan 21 hastanın 18 'inde $(\% 85,7)$ gerekçe; 1 yll içerisinde 3 . ve 4 . doz için başvuruda bulunmaktı. Deksametazon implant için başvuru yapılan 8 hasta $(\% 38,1)$ için başvuru öncesindeki tedavi rejimi ranibizumab idi ve bu hastalar için başvuru gerekçesi yetersiz etkinlik/nüks olarak belirtilmekteydi.

Ranibizumab, SRVT ve RVDT'deki maküla ödeminde etkinliği birçok çalışmada gösterilmiş bir VEBF inhibitörüdür (9-11). Çalışmamızda ranibizumab için başvuru oranı 9 hasta ile \%30 oranında saptanmıştır. Başvuru oranının azlığı, ranibizumabın 17.012013'de ruhsatlı ve geriödemesinin olması, off-label kullanılabilen bevacizumab'in alternatif tedavi seçeneği olarak hekimler tarafından tercih edilmesi ya da o dönemde RVT için de endikasyon dahilinde olan deksametazon implantın RVT'ye bağlı maküler ödemi gidermedeki güçlü etkisiyle açıklanabilir. Bu 9 hastada da gerekçe olarak, glokom ve katarakt riski nedeniyle "deksametazon implant yapılamama" belirtilmiştir.

Aflibercept, RVT için 2014 yılında ruhsatlandırılan ve 2015 yılında geri ödemesini alan bir VEBF inhibitörüdür.
RVT'ye bağlı maküler ödemde etkili olduğu klinik çalışmalarda kanıtlanmasına rağmen (17-20), bizim çalışmamızda 2013 yılında RVT için aflibercept başvurusu yoktu. Bu durum o zamanlar benzer etkilere sahip ranibizumabın VEGF inhibitörü olarak daha öncelikli tercih edilmesine ve ranibizumab'a yanıt alınamayan vakalarda ikincil tedavi olarak, alternatif bir anti-VEBF'den ziyade farklı etki mekanizmasına sahip deksametazon implant'in tercih edilmesiyle açıklanabilir.

Çalışmamızın sonucuna göre; 2013 yilında RVT tedavisinde endikasyon dışı ilaç başvuru oranı deksametazon implant için \%70, ranibizumab için \%30 idi. O dönemde bevacizumab, aflibercept için hiç başvuru yoktu. En az 48 en fazla 85 yaş olmak üzere geniş bir yaş aralı̆ğında başvuru mevcuttu. Kadın ve erkek oranı hemen hemen eşitti. Genellikle tek göz için başvuru daha yüksekti. Hastaların 12 (\%35,3)'si SRVT tanısı ile, $18(\% 52,9)$ 'i RDVT tanısı ile başvuruda bulunmuştu. Ranibizumab için yapılan başvuruların büyük çoğunluğu $(\% 77,8)$ RVDT tanısı ile olurken, deksametazon implant için ise SRVT ve RVDT için başvuru oranları hemen hemen eşitti (sırasıyla \%52,4, \%47,6). Başvurularda talepte bulunulan ilacın, istenilen doz şekilleri incelendiğinde, ranibizumab için yapılan başvuruların hepsinde "1 ay arayla 3 doz", deksametazon implant için ise 12 hastada tek doz, 9 hastada ise 2 doz istemi yapılmıştı.

Çalışmamızda en çok başvuru 20 hasta ile İç Anadolu bölgesine aitti (\%66,7). Bunu 7 hasta ile Ege bölgesi izlemekteydi $(\% 23,3)$. Karadeniz, Güneydoğu Anadolu ve Akdeniz Bölgelerinden ise sadece l'er başvuru mevcuttu. O dönemde Marmara ve Doğu Anadolu bölgelerine ait başvurunun olmaması şaşırtıcı olmakla birlikte hastalığın ülkemizde bölgelere göre dağılım farklılıklarıyla açılanabilir. Başvuruların büyük bir çoğunluğu (24 hasta) açık ara farkla devlet üniversitelerine aitti (\%80). Bunu 4 hasta başvurusu ile eğitim ve araştırma hastanesi izlemekteydi $(\% 13,3)$. Vakıf üniversitelerinden ise sadece 2 hasta başvurusu vardı. (\%5,9). Bölgeler arasındaki farklılık, nüfus yoğunluğunun, daha detaylı takip ve tedaviyi yapacak retina uzmanlarının bulunduğu üniversite ve eğitim araştırma hastanelerinin dağılımındaki farklılıklarla açıklanabilir.

\section{SONUÇ}

Endikasyon dışı ilaç kullanımı başvurularının demografik bilgilerinin değerlendirildiği bu çalışmada ülkemizde 2013 yılında RVT'nin tedavisinde endikasyon dışı ilaç kullanımı başvuru bilgilerinin değerlendirilmesi, literatüre katkısının yanı sıra, Türkiye'deki tedavi seçeneklerimizi belirleme açısından yol gösterici olmaktadır. 


\section{ETİK BEYANLAR}

Etik Kurul Onayı: Bu çalışma için Ankara Dışkapı Eğitim ve Araştırma Hastanesi Klinik Araştırmalar Etik Kurulu tarafından 49/12 karar numarası ile 16.04.2018 tarihinde onaylanmıştır. Tüm dosya incelemeleri için Türkiye İlaç ve Tibbi Cihaz Kurumu Başkanlığı’ndan onam alınmıştır.

Aydınlatılmış Onam: Çalışma retrospektif olarak dizayn edildiği için hastalardan aydınlatılmış onam alınmamıştır.

Hakem Değerlendirme Süreci: Harici çift kör hakem değerlendirmesi.

Çıkar Çatışması Durumu: Yazarlar bu çalışmada herhangi bir çıkara dayalı ilişki olmadığını ve adı geçen ilaçlarla ilgili bir çıkar olmadığını beyan etmişlerdir.

Finansal Destek: Yazarlar bu çalışmada finansal destek almadıklarını beyan etmişlerdir.

Yazar Katkıları: Yazarların tümü; makalenin tasarımına, yürütülmesine, analizine katıldığını ve son sürümünü onayladıklarını beyan etmişlerdir.

\section{KAYNAKLAR}

1. Özcan Büyüktanır BG, Karaosmanoğlu DO. Endikasyon dıșı (off-label) ilaç kullanımından doğan zararlardan ilaç üreticisinin ve hekimin hukuki sorumluluğu. İnönü Üniversitesi Hukuk Fakültesi Derg 2017; 8: 153-98.

2. Turner S. Unregistered and off-label drug use in paediatric patients. Aust J Hosp Pharm 1999; 29: 265-8.

3. Mclntyre J, Conroy S, Avery A, H Corns, I Choonara. Unlicensed and off label prescribing of drugs in general practice. Arch Dis Child 2000; 83: 498-501.

4. Parodi MB, Bandello F: Branch retinal vein occlusion: classification and treatment. Ophthalmologica 2009; 223: 298-305.

5. Wong TY, Scott IU: Clinical practice. Retinal-vein occlusion. N Engl J Med 2010; 363: 2135-44.

6. Royal College of Ophthalmologists: Retinal vein occlusion (RVO): interim guidelines for management of retinal vein occlusion (RVO). London: RCOpth; 2010. Available from: http://www. rcophth.ac.uk/core/core_picker/download.aspid=337

7. Yau JW, Lee P, Wong TY, Best J, Jenkins A. Retinal vein occlusion: an approach to diagnosis, systemic risk factors and management. Intern Med J 2008; 38: 904-10.

8. Glanville J, Patterson J, McCool R, et al. Efficacy and safety of widely used treatments for macular oedema secondary to ratinal vein occlusion: a systemic review. BMC Ophthalmol 2014; 14 : 7.

9. Brown DM, Campochiaro PA, Bhisitkul RB, et al. Sustained benefits from ranibizumab for macular edema following branch retinal vein occlusion: 12-month outcomes of a phase III study. Ophthalmology 2011; 118: 1594-602.

10. Campochiaro PA, Brown DM, Awh CC, et al. Sustained benefits from ranibizumab for macular edema following central retinal vein occlusion: twelve-month outcomes of a phase III study. Ophthalmology 2011; 118:2041-9.

11. Heier JS, Campochiaro PA, Yau L, et al. Ranibizumab for macular edema due to retinal vein occlusions long-term follow-up in the HORIZON trial. Ophthalmology 2012; 119: 802-9.

12. Ferrara N, Hillan KJ, Gerber HP, Novotny W. Disovery and development of bevacizumab, an anti-VEGF antibody for treating cancer. Nat Rev Drug Discov 2004; 3: 391-400.
13. Moradian S, Faghihi H, Sadeghi B, et al. Intravitreal bevacizumab vs. sham treatment in acute branch retinal vein occlusion with macular edema: results at 3 months (Report 1). Graefes Arch Clin Exp Ophthalmol 2011; 249: 193-200.

14. Russo V, Barone A, Conte E, Prascina F, Stella A, Noci ND. Bevacizumab compared with macular laser grid photocoagulation for cystoid macular edema in branch retinal vein occlusion. Retina 2009; 29: 511-5.

15. The SCORE (the standart care vs corticosteroid for retinal vein occlusion) study research group. A randomized trial comparing the efficacy and safety of intravitreal triamcinolone with observation to treat vision loss associated with macular edema secondary to central retinal vein occlusion. Arch Ophthalmol 2009; 127: 1101-14.

16. Mishra SK, Gupta A, Patyal S, et al. Intravitreal dexamethasone implant versus triamcinolone acetonide for macular oedema of central retinal vein occlusion: quantifying efficacy and safety. Int J Retina Vitreous 2018; 4: 13.

17. Brown DM, Heier JS, Clark WL, et al. Intravitreal aflibercept injection for macular edema secondary to central retinal vein occlusion: 1-year results from the phase 3 COPERNICUS study. Am J Ophthalmol 2013; 155: 429-37.e427.

18. Holz FG, Roider J, Ogura Y, et al. VEGF Trap-Eye for macular oedema secondary to central retinal vein occlusion: 6-month results of the phase III GALILEO study. Br J Ophthalmol 2013; 97: 278-84.

19. Korobelnik JF, Holz FG, Roider J, et al. Intravitreal aflibercept injection for macular edema resulting from central retinal vein occlusion: one-year results of the phase 3 GALILEO study. Ophthalmology 2014; 121: 202-8.

20. Boyer D, Heier J, Brown DM, et al. Vascular endothelial growth factor Trap-Eye for macular edema secondary to central retinal vein occlusion: six-month results of the phase 3 COPERNICUS study. Ophthalmology 2012; 119: 1024-32. 